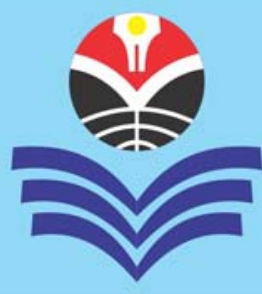

Published every March and September

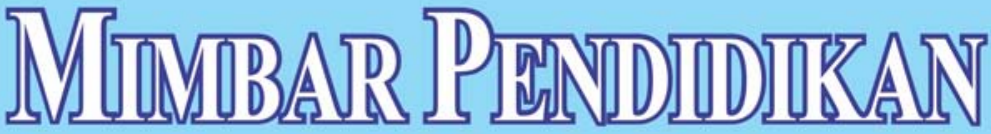

Jurnal Indonesia untuk Kajian Pendidikan

NISA RIZKIAH, ANDI SUWIRTA \& ENCEP SUPRIATNA

\title{
Suara Mahasiswa dari Dua Kota: Perbandingan Pandangan Isola Pos di Bandung dan Balairung di Yogyakarta terhadap Isu Politik di Indonesia, 1991-1998
}

\begin{abstract}
ABSTRAKSI: Pers mahasiswa menjadi media alternatif pada masa pemerintahan Orde Baru (1966-1998). Pers mahasiswa mampu dan berani melakukan kritik terhadap pemerintah melalui tulisan dalam media yang diterbitkannya. Dengan menggunakan metode historis, hasil penelitian menunjukan bahwa pers mahasiswa Indonesia, pada periode tahun 1990-an, mulai menunjukan kembali jatidiri dan perannya. "Isola Pos" di Bandung lebih menitikberatkan pemberitaan pada isu-isu besar pendidikan, hal ini karena pendidikan harus dikelola secara benar, jangan dipolitisir, dan harus sesuai dengan cita-cita para pendiri negara-bangsa. Sedangkan "Balairung" di Yogyakarta lebih dominan pada isu-isu politik, karena ianya merupakan langkah untuk melakukan perubahan dalam konteks sosial-politik sebuah negara-bangsa. Meskipun dari segmentasi berita yang diambil berbeda, namun ada benang merah di antara keduanya, yakni sama-sama memiliki tujuan untuk perubahan Indonesia ke arah yang lebih baik, serta melakukan perlawanan terhadap suatu rezim yang dianggap menyimpang dari kebijakan dan cita-cita bersama.
\end{abstract}

KATA KUNCI: Pers Mahasiswa; Pendidikan; Politik; Pemerintah Orde Baru; Kritik Sosial.

ABSTRACT: "Students' Voice of Two Cities: Comparison on Views of Isola Pos in Bandung and Balairung in Yogyakarta toward Political Issues in Indonesia, 1991-1998". The student's press was an alternative media during the New Order government (1966-1998). The student's press was capable and daring to criticize the government through the publication of articles in the media. By using the historical method, this study shows that student press in the period of 1990s, began showed again its identities and roles. The "Isola Pos" in Bandung was choosing more dominant on educational issues, due to that education must be managed properly, not be politicized, and must accordance with the ideals of nation-states' founders. While "Balairung" in Yogyakarta was more dominant in political issues, due to it was as a step to make changes in the sociopolitical context. Although the news taken from different segments, but there are the common substances between them, namely they have a goal to change Indonesia into a better direction and the resistance to a regime that is wrong in policy and common ideals.

KEY WORD: Student Press; Education; Politics; New Order Government; Social Critics.

About the Authors: Nisa Rizkiah, S.Pd. adalah Alumni Departemen Pendidikan Sejarah FPIPS UPI (Fakultas Pendidikan Ilmu Pengetahuan Sosial, Universitas Pendidikan Indonesia) di Bandung. Andi Suwirta, M.Hum. dan Dr. Encep Supriatna adalah Dosen di Departemen Pendidikan Sejarah FPIPS UPI di Bandung, Jawa Barat, Indonesia. Penulis bisa dihubungi melalui emel di: lawantirani90@gmail.com

Suggested Citation: Rizkiah, Nisa, Andi Suwirta \& Encep Supriatna. (2018). "Suara Mahasiswa dari Dua Kota: Perbandingan Pandangan Isola Pos di Bandung dan Balairung di Yogyakarta terhadap Isu Politik di Indonesia, 1991-1998" in MIMBAR PENDIDIKAN: Jurnal Indonesia untuk Kajian Pendidikan, Volume 3(1), Maret, pp.11-30. Bandung, Indonesia: UPI [Indonesia University of Education] Press, ISSN 2527-3868 (print) and 2503-457X (online).

Chronicle of the article: Accepted (January 15, 2018); Revised (February 17, 2018); and Published (March 30, 2018). 


\section{PENDAHULUAN}

Mahasiswa, sebagai kelompok elite terdidik, memiliki peran penting dalam sejarah suatu negara. Melalui kekuatan ideologi dan intelektualnya, mahasiswa menciptakan sebuah gerakan perubahan yang dikenal dengan nama "gerakan mahasiswa". Banyak perubahan yang dilakukan dalam tatanan kehidupan, baik pada tatanan sosial maupun politik. Keadaan itu terjadi pada hampir seluruh mahasiswa di setiap negara, begitu pula dengan mahasiswa Indonesia (Syuaib, 1987; Saidi, 1989; Sanit, 1999; dan Widjojo \& Noorsalim, 2004).

Sejarah mencatat bahwa beberapa peristiwa besar di Indonesia melibatkan mahasiswa di dalamnya. Seperti berdirinya pemerintahan Orde Baru (1966-1998), yang kemudian mahasiswanya dikenal dengan sebutan Angkatan 1966; peristiwa MALARI, atau Malapetaka 15 Januari, tahun 1974; dan gerakan Reformasi tahun 1998 (Raillon, 1985; Jaya, 1997; Soemardjan ed., 1998; Fadhly ed., 1999; Widjojo et al., 1999; Ali, 2006; dan Gunawan et al., 2009). Beberapa peristiwa yang disebutkan menjelaskan bahwa gerakan mahasiswa di Indonesia mencoba untuk mengambil peran pada sebuah proses perubahan. Dalam prosesnya, banyak cara yang ditempuh oleh mahasiswa Indonesia untuk memperbaiki suatu keadaan, baik dengan cara berdemonstrasi atau menyuarakan aspirasi mereka melalui aksi tulisan dan informasi (Raillon, 1985; Suryadi, 1991; Arismunandar, 2005; dan Suharsih \& Mahendra, 2007).

Namun, jalan yang harus dilalui tidak selalu mulus. Misalnya, para aktivis mahasiswa harus menghadapi pelbagai peraturan yang dibuat oleh pemerintah untuk melumpuhkan gerakan mahasiswa. Pada tahun 1978, misalnya, terjadi pengerdilan gerakan mahasiswa melalui NKK (Normalisasi Kehidupan Kampus) dan BKK (Badan Koordinasi Kampus), yang berfungsi mendomestikasi kekuatan mahasiswa melalui tangan Rektor dan para
Pembantu Rektor yang membidangi bagian kemahasiswaan (Sanit, 1999:171). Keadaan tersebut membuat gerakan mahasiswa menjadi lesu dan mereka bertahan dalam keadaan yang serba sulit. Kondisi itu masih terus berlangsung sampai akhir tahun 1980an (Jaya, 1997; dan Supriyanto, 1998).

Memasuki awal tahun 1990-an, perlahanlahan mulai terbuka jalan bagi proses demokratisasi. Keadaan ini akhirnya mulai mewarnai kehidupan sosial yang ditandai dengan lahirnya gerakan pro-demokrasi di kalangan masyarakat dan mahasiswa. Seiring munculnya berbagai gerakan prodemokrasi, fenomena diskusi kembali bergelora di kalangan mahasiswa, dan banyak kelompok studi bermunculan (Uhlin, 1998; Sanit, 1999; dan Gunawan et al., 2009). Kemunculan gerakan tersebut sebagai jalan aman bagi aktivitas mahasiswa pada kondisi zaman yang represif, sehingga kegiatannya lebih mengarah kepada refleksi pemikiran, tidak pada kerangka aksi (Syuaib, 1987:51). Dari kelompok studi itulah kemudian bermunculan pers mahasiswa.

Konteks pers mahasiswa menjadi lebih menarik, karena tugas mereka bukanlah sebagai jurnalis seperti yang terjadi pada media umum. Pers mahasiswa merupakan penerbitan di kampus, yang pengelolanya murni dilakukan oleh mahasiswa. Penerbitan kampus merupakan jaringan aktivis yang relatif terorganisir, di samping kelompok komite aksi mahasiswa. Selain itu, apa yang disuguhkan oleh pers mahasiswa dalam pemberitaannya berbeda dengan yang diberitakan oleh media umum. Berita yang disuguhkan lebih bersifat ideologis dan banyak mengandung kritik sosial terhadap keadaan atau kebijakan pemerintah. Pers mahasiswa juga mencoba untuk selalu bertahan di tengah kebijakan pemerintah mengenai pemberedelan media (Supriyanto, 1986; Abrar, 1992:7; dan Kresna, 2016).

Keberadaan pers mahasiswa menjadi semacam kekuatan bersama bagi beragam 
gerakan yang tengah menggeliat dalam merespon arus besar perubahan sosialpolitik. Kondisi itulah yang membuat pers mahasiswa sebagai sebuah gerakan yang memiliki sebuah karakteristik yang khas mahasiswa (Siregar, 1983; Raillon, 1985; Arismunandar, 2005; Syahriah, 2009; dan Fathoni et al., 2012).

Dalam kajian sejarah pers, kondisi ini menjadi menarik dan penting bagi penulis, karena sampai saat sekarang masih jarang yang melakukan penelitian mengenai pers mahasiswa. Selain itu, pers mahasiswa bisa disebut sebagai creative minority, yang mampu menembus tirai pembungkaman terhadap dunia jurnalistik pada masa pemerintahan Orde Baru (1966-1998). Politik dan pendidikan menjadi titik penting dalam penerapan berbagai kebijakan pemerintah. Mereka merasa tergugah untuk mengkritisi apa yang mereka pandang sebagai pengkhianatan rezim terhadap katakatanya sendiri (Freire, 1999; Syahriah, 2009; dan Hill, 2011:140).

Fokus penelitian ini mengambil dua pers mahasiswa yang ada di dua kota besar Indonesia, yaitu Bandung dan Yogyakarta. Mengapa penulis memilih Bandung dan Yogyakarta, karena dua kota itu merupakan salah satu simpul gerakan mahasiswa di wilayah pulau Jawa (Aspinall, 1999; Latif, 2005; Sulastomo, 2008; dan Arrozy, 2013). Sejak tahun 1980-an, di beberapa kota besar di Indonesia, terutama Jakarta, Bandung, dan Yogyakarta, banyak kelompok studi mulai muncul dan meluas. Kelahirannya lebih banyak disebabkan oleh kesamaan kondisi yang tidak toleran terhadap kegiatan politik praktis. Mereka mencoba mencari alternatif baru dalam sebuah gerakan mahasiswa, tanpa aksi. Kelompok-kelompok studi ini akhirnya memilih jalur penyadaran melalui bidang informasi (Syuaib, 1987:51; dan Ali, 2006).

Begitu pula dengan Bandung, kota yang terletak di jantung Tanah Pasundan. Bandung merupakan induk dari kegiatan administrasi, ekonomi, dan intelektual (Raillon, 1985:23; Kartodiwirio, 2006; Suganda, 2007; dan Luftiany \& Santosa, 2014). Arus informasi bergerak dengan cepat. Secara historis, banyak gerakan mahasiswa yang cukup besar dan berpengaruh pernah ada di kota Bandung (Harahap, 1993; Fadhly ed., 1999; Sanit, 1999; dan Matulessy, 2005). Seperti disebutkan di atas, Bandung termasuk dalam simpul gerakan mahasiswa pada periode 1990-an, dimana saat itu banyak berkembang gerakan mahasiswa.

Selain itu, Bandung memiliki banyak universitas dan macam-macam institut. Salah satunya adalah IKIP (Institut Keguruan dan Ilmu Pendidikan) Bandung, yang sejak tahun 2000-an berubah menjadi UPI (Universitas Pendidikan Indonesia). Di IKIP Bandung banyak gerakan mahasiswa muncul dan berkembang pada awal tahun 1990-an, dan salah satunya adalah pers mahasiswa Isola Pos (Mardiansyah, 2007; dan Sirat, 2011). Isola Pos ini merupakan pers mahasiswa yang turut-serta membidani lahirnya pers-pers mahasiswa lainnya di kota Bandung. Oleh karena itu, penulis memilih Isola Pos sebagai bahan kajian.

Sedangkan Yogyakarta terkenal dengan salah satu kampus terbesar di Indonesia, yaitu UGM (Universitas Gadjah Mada). UGM menjadi salah satu motor gerakan mahasiswa di Yogyakarta, dimana para mahasiswa sudah mulai kritis dengan adanya kelompok studi dan pers mahasiswa (Purwanto, Suryo \& Padmo eds., 1999; dan Gunawan et al., 2009:69). Alasan lainnya penulis memilih UGM, karena ingin membandingkan pers mahasiswa dari lembaga keguruan dan non-keguruan. UGM memiliki pers mahasiswa yang bernama Balairung. Sebagai pers mahasiswa, Balairung merupakan salah satu barometer pers mahasiswa di wilayah Jawa Tengah; yang mana ia juga turut aktif dalam kegiatan-kegiatan pers nasional (Hidayat, 1992; dan Asshibbamal, 2011). 
Dalam penelitian ini, topik yang diangkat adalah tentang isu politik. Alasan penulis memilih isu tersebut dalam frame pemberitaan pers mahasiswa, karena pada periode 1990-an hal tersebut merupakan isu yang penting untuk dibahas. Maka dari itu, banyak pers mahasiswa pada tahun 1990an yang mengangkat isu tersebut dalam pemberitaannya (Sedayu, 2004; Eriyanto, 2009; dan Widjojo \& Noorsalim, 2004). Khususnya isu politik, ia memiliki ciri khas sendiri.

Setiap pers mahasiswa berbeda karakteristiknya dalam pemberitaan. Ada yang berani, lugas, dan tegas, namun ada pula yang menggunakan sindiran-sindiran halus dan menggunakan gaya bahasa yang sopan (Raillon, 1985; Supriyanto, 1998; Arismunandar, 2005; dan Utomo, 2013). Maka, penulis merasa tertarik untuk melakukan penelitian terhadap isu politik dalam bingkai pemberitaan pers mahasiswa.

\section{METODE PENELITIAN}

Penulis mengggunakan metode historis, dengan studi literatur dan wawancara sebagai teknik penelitian (Kuntowijoyo, 2003; Ismaun, 2005; dan Sjamsuddin, 2007). Langkah-langkah penelitian menggunakan metode historis adalah sebagai berikut: pertama, memilih topik yang sesuai; dan kedua, mengusut semua evidensi atau bukti yang relevan dengan topik. Dalam hal ini, penulis mencari dan mengumpulkan datadata terkait dengan pers mahasiswa pada masa Orde Baru dengan menggunakan studi literatur atau studi kepustakaan.

Kemudian, ketiga, membuat catatan tentang apa saja yang dianggap penting dan relevan dengan topik yang ditentukan ketika penelitian sedang berlangsung. Keempat, mengevaluasi secara kritis semua evidensi yang telah dikumpulkan melalui kritik sumber. Kritik dilakukan terhadap semua sumber yang dihimpun peneliti tentang pers mahasiswa untuk memperoleh data yang relevan.
Berikutnya, kelima, menyusun hasil-hasil penelitian atau catatan fakta-fakta ke dalam suatu pola yang benar dan berarti, yaitu sistematika tertentu yang telah disiapkan sebelumnya. Catatan hasil penelitian disusun dalam sebuah sistematika baku yang berpedoman pada buku, Pedoman Penulisan Karya Ilmiah, ketika karya ilmiah ini dikerjakan (UPI, 2013).

Terakhir, keenam, menyajikan dalam suatu cara yang dapat menarik perhatian dan mengkomunikasikannya kepada para pembaca, sehingga dapat dimengerti sejelas mungkin. Sedangkan untuk pengumpulan data, penulis melakukan teknik studi literatur, yaitu mengkaji sumber-sumber yang relevan dengan kajian penulis.

Selain studi literatur, penulis juga menggunakan sumber lisan yang diperoleh melalui wawancara dengan beberapa tokoh yang terlibat (Stake, 1994; Kuntowijoyo, 2003; Sjamsuddin, 2007; dan Mulyana, 2013), baik secara langsung maupun tidak, dalam perjalanan pers mahasiswa Isola Pos di IKIP Bandung dan Balairung di UGM Yogyakarta, tahun 1991-1998.

\section{HASIL PENELITIAN DAN PEMBAHASAN}

Dari Kelompok Studi Menuju "Isola Pos”. Kebijakan NKK/BKK (Normalisasi Kehidupan Kampus / Badan Koordinasi Kampus) pada masa pemerintahan Orde Baru (1966-1998) mulai mengendur seiring perkembangan waktu. Memasuki medio tahun 1980-an, beberapa kegiatan mahasiswa di kampus mulai terbangun dari tidur panjangnya. Meskipun masih berada dalam pengawasan pihak Rektorat, jawaban dari pembungkaman terhadap aktivitas mahasiswa selama NKK/BKK adalah munculnya kelompok-kelompok studi di berbagai kampus (Kaisiepo, 1978; Dipopramono, 1989; Jaya, 1997; dan Supriyanto, 1998).

Baik itu di Bandung, Jakarta, maupun Yogyakarta, kelompok studi 
yang sebelumnya redup, kini kembali bermunculan (Saidi, 1989; Cula, 1999; dan Muntaha, 1999). Begitu pun yang terjadi di IKIP (Institut Keguruan dan Ilmu Pendidikan) Bandung, muncul sebuah kelompok studi yang bernama Kelompok Studi Lingkar (Sirat, 2011).

Awalnya, Kelompok Studi Lingkar ini digagas oleh beberapa mahasiswa saja. Namun, seiring berjalan waktu, anggotanya semakin bertambah. Secara filosofis, Lingkar berarti lingkaran, namun bila disempitkan maka menjadi titik. Oleh karenanya, apa yang dilakukan oleh para anggotanya akan menentukan keberadaan Lingkar: apakah akan menjadi lingkaran yang besar atau sekedar menjadi titik. ${ }^{1}$

Dibentuknya Lingkar, tentu saja, memiliki cita-cita besar, karena ia lahir atas kemandekan yang terjadi pada mahasiswa, khususnya dalam bidang penalaran. ${ }^{2}$ Dari kelompok studi inilah nantinya akan melahirkan pers mahasiswa di dalam kampus (Ali, 2006:115). Maka, Kelompok Studi Lingkar memiliki cita-cita untuk membentuk lembaga pers mahasiswa dan menerbitkan media (wawancara dengan Agus R. Sarjono, 1/8/2009).

Dua tahun setelah berdiri, Lingkar semakin mantap untuk mendirikan UKM (Unit Kegiatan Mahasiswa) dan UPM (Unit Pers Mahasiswa) di dalamnya. Para anggota Lingkar saat itu, seperti Agus R. Sarjono, Sumiyadi, Khalid A. Harras, dan yang lainnya mengajukan proposal pembentukan

\footnotetext{
${ }^{1}$ Lihat, misalnya, "Unit Pers Mahasiswa UPI: The Brief History”, Artikel Tanpa Nama Pengarang, Tidak Diterbitkan, Bandung: UPM UPI [Unit Pers Mahasiswa, Universitas Pendidikan Indonesia], 2003; serta wawancara dengan Agus R. Sarjono, penggagas dan pendiri Kelompok Studi Lingkar dan Isola Pos, di Depok, Jawa Barat, Indonesia, wawancara dilakukan oleh Rudini Sirat, pada tanggal 1 Agustus 2009.

${ }^{2}$ Lihat juga "Sebuah Perjalanan Panjang Unit Penerbitan Mahasiswa IKIP Bandung: Mengapa Musti Ada?", Artikel Tanpa Nama Pengarang, Tidak Diterbitkan, Bandung: UPM UPI [Unit Pers Mahasiswa, Universitas Pendidikan Indonesia], 2004; serta wawancara via e-mail dengan Dwi Joko Widiyanto, mantan Pemimpin Redaksi Isola Pos, pada tanggal 27 Juni 2014.
}

UKM dan UPM kepada Pembantu Rektor III IKIP Bandung, Drs. Karna Yudibrata. Usulan itu diterima oleh pihak Rektorat, dengan keluarnya "Surat Keputusan Pembantu Rektor III IKIP Bandung tentang Pembentukan UPM IKIP Bandung, Tanggal 21 Desember 1987”, dengan Agus R. Sarjono sebagai Ketua. ${ }^{3}$ Lahirnya UPM ini sebagai salah satu jawaban atas stagnasi gerakan mahasiswa, khususnya pers pasca NKK/BKK tahun 1978 (Kaisiepo, 1978; Dipopramono, 1989; Jaya, 1997; dan Supriyanto, 1998).

Pada masa awal berdirinya, UPM harus menghadapi beberapa masalah, seperti dilarangnya penggunaan kata "Pers" oleh pemerintah bagi seluruh pers mahasiswa dan harus menggantinya dengan nama "Penerbitan". Kondisi ini tidak menyurutkan semangat pegiat pers mahasiswa, termasuk UPM IKIP Bandung. Pada tahun 1989, UPM mengganti namanya, dari "Unit Pers Mahasiswa" menjadi "Unit Penerbitan Mahasiswa". ${ }^{4}$ Meskipun namanya telah berubah menjadi "Unit Penerbitan Mahasiswa", namun ianya tidak mengubah esensi lembaga, yaitu populis dan kritis (wawancara dengan Agus R. Sarjono, 1/8/2009; wawancara dengan Dwi Joko Widiyanto, 27/6/2014).

Masalah lain yang harus dihadapi adalah persoalan penerbitan, karena setelah empat

${ }^{3}$ Lihat "Surat Keputusan Pembantu Rektor III IKIP Bandung tentang Pembentukan UPM IKIP Bandung, Tanggal 21 Desember 1987", Arsip Tidak Diterbitkan dan Salinan Copy, ada pada Penulis; serta wawancara dengan Agus R. Sarjono, penggagas dan pendiri Kelompok Studi Lingkar dan Isola Pos, di Depok, Jawa Barat, Indonesia, wawancara dilakukan oleh Rudini Sirat, pada tanggal 1 Agustus 2009.

${ }^{4}$ Lihat kembali "Sebuah Perjalanan Panjang Unit Penerbitan Mahasiswa IKIP Bandung: Mengapa Musti Ada?", Artikel Tanpa Nama Pengarang, Tidak Diterbitkan, Bandung: UPM UPI [Unit Pers Mahasiswa, Universitas Pendidikan Indonesia], 2004; serta wawancara dengan Agus R. Sarjono, penggagas dan pendiri Kelompok Studi Lingkar dan Isola Pos, di Depok, Jawa Barat, Indonesia, wawancara dilakukan oleh Rudini Sirat, pada tanggal 1 Agustus 2009; dan wawancara via e-mail dengan Dwi Joko Widiyanto, mantan Pemimpin Redaksi Isola Pos, pada tanggal 27 Juni 2014. 
tahun berdiri, UPM belum bisa untuk menerbitkan sebuah media (Mardiansyah, 2007:28). Hambatan lainnnya juga beragam, dari mulai persoalan anggota yang belum bisa menulis, izin terbit, sampai pada persoalan finansial. Akhirnya, mereka menemukan nama yang dianggap cocok, seperti dijelaskan oleh Rudini Sirat (2011), sebagai berikut:

Ide mereka muncul dari sebuah pandangan, bahwa IKIP Bandung bermula dari sebuah Villa yang bernama Isola. Akhirnya Isola Pos ditetapkan sebagai nama media yang akan diterbitkan UPM. Kata Pos adalah untuk mewujudkan media sebagai lintasan atau sarana ide. Pertimbangan penggunaan nama Isola Pos tak sekedar daya tarik gedung tersebut, tapi memaknai nilai-nilai historis dan filosofi bangunan itu. Pertimbangan historis terletak pada kegiatan jurnalistik, yaitu bangunan tersebut merupakan hasil dari usaha kantor berita, yang dimiliki seorang milyarder berkebangsaan Italia, Baretty (Sirat, 2011:190).

Setelah nama Isola Pos disepakati, selanjutnya mereka memikirkan bagaimana mendapatkan SIT (Surat Izin Terbit) dari pemerintah. Setelah lama mengurus surat izin, ternyata SIT tidak kunjung diterbitkan. Keinginan untuk terbit semakin besar, hingga akhirnya mereka mengantongi "Surat Keputusan Menteri Penerangan Republik Indonesia, Nomor:1795/SK/Ditjen PPG/ STT/1993, Tanggal 23 April 1993" (dalam Sirat, 2011:92).

Sejak saat itu, Isola Pos tidak lagi dibayangi oleh persoalan legalitas formal. Pada tahun yang sama, 1993, Isola Pos juga mendapatkan ISSN (International Standard Series Number), yang pusatnya berada di Paris, Perancis, dan dikeluarkan oleh PDII LIPI (Pusat Dokumentasi Ilmiah dan Informasi, Lembaga Ilmu Pengetahuan Indonesia) di Jakarta (Mardiansyah, 2007; Sirat, 2011; dan wawancara dengan Agus R. Sarjono, 1/8/2009).

"Balairung": Berawal dari Sebuah Kegelisahan. Terbukanya keran demokrasi di Indonesia tidak hanya dirasakan oleh wilayah yang dekat dengan ibukota Jakarta, seperti Bandung, misalnya. Sebuah kota yang berjarak kurang-lebih 500 kilometer dari Jakarta juga merasakan hal yang sama. DI (Daerah Istimewa) Yogyakarta, atau lebih familiar dikenal dengan nama Yogyakarta atau Yogya, merasakan iklim serupa, yakni adanya perubahan arus dan keterbukaan. Yogyakarta juga memiliki banyak universitas, maka jumlah mahasiswa di Kota Yogyakarta terbilang banyak. Salah satu kampusnya yang cukup terkenal dan besar adalah UGM (Universitas Gadjah Mada). Kelompok studi dan gerakan mahasiswa juga turut tumbuh subur di kampus ini (Purwanto, Suryo \& Padmo eds., 1999; Saputra, 2012; dan Pratiwi, 2013).

Yogyakarta, dalam sejarahnya, mencatat beberapa aksi besar mahasiswa, yang terjadi di sana; termasuk beberapa perkumpulan yang cukup terkenal dan memiliki pengaruh di Tanah Air, juga lahir dan berkembang di sana. Beberapa aktivis mahasiswa yang berpengaruh juga terdapat di Yogyakarta, seperti Budiman Sudjatmiko, Nezar Patria, dan Andi Munajat (Pratiwi, 2013; dan Puthut, 2015).

Begitu pula setelah diberlakukannya NKK/BKK (Normalisasi Kehidupan Kampus / Badan Koordinasi Kampus), beberapa aktivis mahasiswa masih bisa menjalankan kegiatan, seperti misalnya tumbuh beberapa kelompok studi. Namun, apa yang terjadi di Yogyakarta, khususnya di UGM, berbeda dengan di Bandung. Kemunculan pers mahasiswa tidak didahului oleh kelompok studi, seperti halnya pers mahasiswa Balairung, yang masih ada sampai saat ini (Jaya, 1997; Purwanto, Suryo \& Padmo eds., 1999; dan Asshibbamal, 2011).

Sebelum BPPM (Badan Penerbitan Pers Mahasiswa) Balairung terbentuk, di UGM sudah ada pers mahasiswa yang bernama Gelora Mahasiswa (Dhakidae, 1977; dan Asshibbamal, 2011). Persoalan 
NKK/BKK tidak menjadi masalah yang krusial, karena Rektor UGM saat itu, Soekadji Ranoewihardjo, tetap mendukung berjalannya kegiatan mahasiswa di kampus, termasuk pers mahasiswa. Penerbitan mahasiswa berada langsung di bawah tanggung jawab Rektor (Supriyanto, 1998:77). Namun itu tidak berlangsung lama, belum genap satu tahun, akhirnya Gelora Mahasiswa dibredel oleh Rektor UGM sendiri, karena terlalu gencar memberitakan dan mengkritisi persoalan kebijakan NKK/BKK (Purwanto, Suryo \& Padmo eds., 1999; dan Asshibbamal, 2011).

Mulanya, cikal-bakal penerbitan pers mahasiwa tingkat universitas di UGM digagas oleh penerbitan fakultas/jurusan. Sedikitnya terdapat 47 penerbitan fakultas dan jurusan, 29 di antaranya masih aktif dan minimal terbit setiap semester (Supriyanto, 1998:92). Dari sanalah, setiap pemimpin penerbitan pada tanggal 29 Oktober 1985, menyelenggarakan Seminar Pers Mahasiswa se-UGM di University Club. Dalam pembahasannya, mereka menyepakati untuk dihidupkan kembali pers mahasiswa tingkat universitas. Seperti dikemukakan oleh Lubabun Ni'am S. Asshibbamal (2011), tentang cikal-bakal kelahiran majalah Balairung di Yogyakarta, berikut ini:

Seminar yang diikuti oleh 90 mahasiswa itu mengusung tiga tujuan. Pertama, menelurkan konsep pers mahasiswa yang ideal. Kedua, membuat pers mahasiswa yang bersifat universitas. Ketiga, merangsang kegairahan penerbitan ilmiah yang ada di tingkat fakultas dan/atau jurusan. Seminar itu menyepakati bentuk penerbitan majalah.

Dari hasil pertemuan disepakati bentuk media yang akan diterbitkan adalah majalah. Pemilihan itu berdasar pada waktu terbit majalah yang relatif lebih panjang dibanding koran atau buletin. Maka apa yang akan dituliskan bisa dipikirkan dengan matang dan mendalam. Dalam pertemuan itu disepakati juga bahwa majalah yang akan diterbitkan harus tidak terlepas dari kecendikiaan mahasiswa sebagai warga terdidik. Termasuk orientasi mahasiswa harus kepada penciptaan masa depan yang lebih baik. Hal itu menjadi penting, mengingat negara tengah bersikap represif dan otoriter (Asshibbamal, 2011:182).

Nama Balairung sendiri diambil dari salah satu nama gedung yang ada di kampus UGM (Universitas Gadjah Mada) di Yogyakarta. Nama bangunan Balairung itu juga diambil karena memiliki makna filosofis. Ia menjelaskan bahwa Balairung merupakan sebuah tempat yang berada di istana, di mana tempat itu digunakan untuk bertemunya raja dengan rakyat. Dari nama Balairung ini ada sebuah makna yang elitis juga idealis (Asshibbamal, 2011; dan wawancara dengan Kelik Supriyanto, 26/5/2014).

Setelah nama itu dipilih, kemudian diajukan kepada Rektor UGM saat itu, Prof. Dr. T. Jacob, lengkap dengan tagline-nya "nafas intelektual mahasiswa" beserta logo triplekung. Majalah ini memiliki orientasi intelektual yang kuat dengan penampilan yang serius pada sebagian besar artikelnya. Semula, Balairung direncanakan terbit sebulan sekali, namun setelah dievaluasi maka ditetapkan terbit setiap tiga bulan (Supriyanto, 1998:92; dan Asshibbamal, 2011).

Setelah menunggu selama enam bulan, maka Balairung mendapatkan "Surat Keputusan Menteri Penerangan Republik Indonesia, Nomor: 1039/SK/Ditjen PPG/ STT/1986" secara resmi. Balairung juga mendapatkan ISSN (International Standard Series Number) dengan nomor 0215-076X, serta "Surat Keputusan Rektor UGM Nomor: UGM/82/7798/UM/01/37”, yang diikuti pencantuman status Balairung sebagai "Unit Penerbitan Pers Mahasiswa UGM" (dalam Asshibbamal, 2011:188). Maka, setelah ada izin terbit, majalah Balairung edisi selanjutnya dianggap sebagai edisi perdana dengan nomor: 1/ Th.I/1986. Hal ini ditujukan demi lagalitas penerbitan (Supriyanto, 1998; dan Asshibbamal, 2011). 
Pembahasan. Pada periode awal tahun 1980-an, pemerintahan Soeharto mulai menunjukan kekuatan dan dominasinya (Poesponegoro \& Notosusanto eds., 1993; dan Jenkins, 2010). Pada awal tahun 1980an memang terjadi krisis, karena harga minyak yang jatuh. Akan tetapi, pada saat itu, seperti disebutkan oleh banyak peneliti dan pengkaji, bahwa kekuatan personal Presiden Soeharto dalam mempertahankan kekuasaan sudah tak tertandingi, dan dia tetap bertahan dalam posisi tersebut sampai dekade berikutnya ( $c f$ Sen \& Hill, 2001:6; Sudibyo, 2001; Harahap, 2006; dan Suwirta, 2017).

Namun, menjelang akhir era 1980-an, kekuasaan yang dibangun oleh Presiden Soeharto itu mulai menunjukan kerawanan. Salah satunya karena tercipta konglomerasi dan KKN (Korupsi, Kolusi, Nepotisme) dari kalangan keluarga Presiden Soeharto, yaitu anak-anaknya dan kawan-kawan Soeharto sendiri. Kondisi ini membuat masyarakat mulai tidak mempercayai kepimpinan Presiden Soeharto (Sastrosatomo, 1998; Firdaus, 1999; Winters, 1999; dan Elson, 2005:509).

Faktor lain yang menyebabkan kerawanan tersebut adalah banyaknya penyelewangan pada pembangunanpembangunan yang tengah dilakukan. Selain itu, setelah sekian lama keadaan yang menghimpit dan meranggaskan pohon intelektual, kini pohon tersebut mulai kembali bersemi yang ditandai dengan munculnya kelas menangah. Lahirnya kelas menengah, seperti golongan cendekiawan dan mahasiswa, mulai menuntut transparansi dalam pemerintahan, termasuk menuntut partisipasi politik yang lebih langsung (Haris \& Sihbudi eds., 1995; Muntaha, 1999; dan Ricklefs, 2008).

Keberadaan golongan intelektual menjadi penting, karena kehadiran mereka itu semakin dibutuhkan di tengah krisis ekonomi dan politik yang kian kronis. Dalam kondisi seperti itu, pemerintah bisa melakukan apa saja, dan pemerintah bagaikan gelap mata. Hanya ada kekuasaan dalam pandangannya dan tidak akan lagi memperhatikan nasib rakyat (Mahasin ed., 1984; Said, 1998; Winters, 1999; Markoff, 2002; dan Syahriah, 2009).

Golongan intelegensia, termasuk mahasiswa, tidak dapat mengelakan diri dari tanggungjawab dengan mengatakan bahwa sebagai golongan yang kecil di dalam negara demokrasi, mereka tidak dapat menundukan golongan terbanyak. Pada kondisi seperti itu, tentu mereka tidak berbicara jumlah yang banyak, namun bagaimana gerakan yang dilakukan oleh golongan kelas menengah tersebut adalah untuk memperbaiki kondisi Indonesia (Hatta, 1953; Mahasin ed., 1984:15; dan Kuntowijoyo, 1985).

Dari hari ke hari, selama periode tahun 1990-an, pemerintahan Presiden Soeharto semakin terpuruk. Ditambah dengan kondisi Presiden Soeharto yang sudah semakin tua dan lelah. Kondisi yang terjadi adalah kehidupan kampus mulai bersemi kembali, gerakan mahasiswa kembali menemukan ruhnya. Kegiatan diskusi dan penalaran kembali digelar (Surdiasis, 1995; dan Syafa'at, 2008).

Melihat masyarakat mulai bergeliat dan dukungan terhadap dirinya semakin berkurang, maka Presiden Soeharto mencari jalan lain. Jalan yang dipilihnya adalah dengan mengorganisir kelompok intelektual Muslim. Padahal, selama ia berkuasa hampir 25 tahun, tidak pernah ada kedekatan antara Presiden Soeharto dengan tokohtokoh Muslim. Akhirnya dibentuk ICMI (Ikatan Cendekiawan Muslim Indonesia). Kelompok ini memang tidak dimaksudkan untuk berperan aktif dalam politik, akan tetapi mewakili aspirasi kelompok yang makin menguat. ICMI diketuai oleh salah seorang Menteri kesayangan Presiden Soeharto, yakni Baharuddin Jusuf Habibie (Winters, 1999; Elson, 2005:515; dan Ricklefs, 2008). 
Presiden Soeharto berpandangan bahwa apabila B.J. (Baharuddin Jusuf) Habibie yang menjadi pemimpin ICMI, maka organisasi cendekiawan Muslim tersebut tidak akan berkembang menjadi kelompok Islam radikal (Hefner, 1993; dan Ricklefs, 2008). Pada tahun 1994, ICMI sudah memiliki anggota resmi sebanyak 20,000 orang dan merangkul orang-orang Muslim dari berbagai warna agama dan politik (Elson, 2005:515; dan Ricklefs, 2008). Kondisi ini menunjukan bahwa antusiasme masyarakat terhadap sebuah kelompok cendekia baru cukup tinggi dan direspon positif. Kenyataan itu membuat Presiden Soeharto bisa sedikit bernafas lega (Ricklefs, 2008).

Akan tetapi, persoalan kerawanan pemerintahan Presiden Soeharto belum selesai sampai di sana. Hubungan ABRI (Angkatan Bersenjata Republik Indonesia) dan Presiden Soeharto mulai renggang dan timbul rasa saling tidak percaya. Apalagi setelah diumumkan hasil sidang umum MPR RI (Majelis Permusyawaratan Rakyat Republik Indonesia), bulan Maret 1993, yang kembali memilih Soeharto sebagai Presiden untuk keenam kalinya (Schwarz, 1994; dan Ricklefs, 2008:675).

Presiden Soeharto biasanya selalu bisa memilih Wakil Presiden sendiri. Kali ini yang dipilihnya adalah Sudharmono, seseorang yang tidak terlalu disukai oleh kalangan ABRI. Sedangkan kalangan ABRI mengajukan Jenderal Try Sutrisno sebagai Wakil Presiden. Dalam kondisi seperti itu sudah terlihat keretakan hubungan antara Presiden Soeharto dengan ABRI (Soeharto, 1989; Pour, 2007; dan Ricklefs, 2008).

Kondisi tersebut juga diperburuk dengan munculnya konflik sosial dan agama di beberapa daerah. Misalnya konflik agama yang terjadi di Jakarta pada tahun 1992, antara kaum Muslim dan non-Muslim. Selain itu, di Surabaya pada taun 1993 terjadi pembunuhan terhadap seorang wanita aktivis buruh bernama Marsinah.
Persoalan konflik agama juga terjadi di Timor-Timur, dimana sejumlah Muslim di sana, sekitar 20,000 orang, menderita berbagai bentuk diskriminasi (Uhlin, 1998:35; dan Rumagit, 2013).

Memasuki pertengahan tahun 1990-an, kondisi politik nasional dan ekonomi semakin tidak menentu. Terjadi penyerangan, pada tanggal 27 Juli 1996, terhadap kantor PDI (Partai Demokrasi Indonesia) di Jalan Diponegoro di Menteng, Jakarta. Dalam kejadian itu, sekitar 20 orang tidak diketahui nasibnya dan 5 orang meninggal dunia. Ini disebabkan karena Presiden Soeharto ingin menghancurkan aspirasi politik Megawati Soekarnoputri. Tidak hanya itu, PRD (Partai Rakyat Demokrasi) juga mengalami hal serupa. PRD yang dipimpin oleh seorang aktivis bernama Budiman Sudjatmiko ikut dibubarkan. Presiden Soeharto berpandangan bahwa kerusuhan itu disebabkan oleh sekolompok orang yang menolak untuk mematuhi konstitusi (Bhakti et al., 2001; dan Elson, 2005:548-549).

Selain kerusuhan di tahun 1996, memasuki tahun 1997, krisis ekonomi mulai melanda Indonesia. Kondisi itu menimbulkan kesenjangan antara harapan dan kenyataan. Masyarakat kelas menengah Indonesia yang selama ini patuh pada rezim Orde Baru, mulai gelisah dan mendukung gerakan Reformasi yang dimotori oleh para mahasiswa (Fadhly ed., 1999; dan Arismunandar, 2005:47). Bagaimana mungkin kelas menengah hanya bisa diam, sedangkan kondisi masyarakat sudah semakin memprihatinkan. Beras dan kebutuhan pokok lainnya hilang dari pasaran, kalaupun ada harganya tidak akan terjangkau oleh masyarakat kecil. Nilai tukar Rupiah terhadap Dollar Amerika Serikat pun anjlok, yakni menyentuh angka Rp. 10,000. Kondisi ekonomi mulai berantakan, apa yang telah dibangun selama puluhan tahun, disapu bersih oleh krisis moneter (Aspinall, 1999; Ahmad \& Suwirta, 
2007; dan Ricklefs, 2008).

Selama krisis ekonomi, mahasiswa dari berbagai kota besar di Indonesia turun ke jalan di Jakarta dan menuntut lengsernya Soeharto dari kursi Presiden. Keadaan semakin kacau, karena banyak mahasiswa yang hilang tak jelas rimbanya dan/atau mati. Belum lagi terjadi kerusuhan anti-Cina di beberapa daerah, yang diiringi dengan penjarahan pertokoan milik orang-orang Cina. Kondisi beberapa kota, seperti Jakarta, Bandung, Yogyakarta, dan Medan, turut bergejolak. Sampai pada akhirnya, Presiden Soeharto tidak mampu lagi mempertahankan kepemimpinannya. Akhirnya, tepat pada bulan Mei 1998, ia memutuskan untuk mundur dari jabatannya sebagai Presiden (Aspinall, 1999; Fadhly ed., 1999; Ahmad \& Suwirta, 2007; dan Ricklefs, 2008).

Apa yang dilakukan oleh pers mahasiswa pada periode itu adalah mencoba mengkritisi berbagai kebijakan atau sikap politik pemerintah Orde Baru. Pada bagian ini akan dibahas mengenai bagaimana pandangan kedua pers mahasiswa, yakni Isola Pos di Bandung dan Balairung di Yogyakarta, terhadap kebijakan-kebijakan politik pemerintah Orde Baru pada kurun waktu 1990-1998. Hal tersebut akan dilihat dari tajuk rencana, catatan pojok, dan karikatur yang dibuat oleh kedua media mahasiswa. Tajuk rencana, catatan pojok, dan karikatur, bahkan juga kolom Surat Pembaca, adalah merupakan sikap dan pandangan, atau views, dari sebuah media massa (Makah, 1977; Parera, 1977; Sudarta, 2007; dan Suwirta, 2000 dan 2015).

Melalui tulisan yang cukup berani dan keras, mereka menyuarakan keadilan. Seperti yang dituliskan oleh Isola Pos di Bandung, pada tahun 1993, dalam tajuknya yang berjudul "Hukum Rakyat Telah Tumbang", yang menegaskan sebagai berikut:

Melihat beberapa kasus hukum nasional yang sempat mengemuka dan rentannya hukum perburuhan (kasus pernbunuhan buruh Marsinah), yang banyak meletup di desa-desa, menjamurnya calo tanah, terdesaknya lahan-lahan pertanian rakyat oleh gemuruh industrialisasi (kasus Nipah). Ini membuktikan bahwa negara tidak bisa lagi berlindung dibalik justifikasi kultural jika menghadapi gejolak demokrasi dan penegakan hukum. [...]

Maka, masalah penegakan hukum sebenarnya terletak kepada ada tidaknya keinginan politik (political will) negara (baca penguasa) untuk membuka pintu dialog, membuka sekat-sekat birokrasi yang tertutup, dan memberikan peluang kepada "virus" demokrasi untuk berkembang biak serta kesediaan negara untuk membuka diri terhadap pemikiran-pemikiran alternatif.

Dari tajuk di atas tergambar bahwa Isola Pos di Bandung berpandangan mengenai transparansi hukum di Indonesia masih sangat rendah. Terbukti dari banyaknya kasus kerusuhan atau pelanggaran HAM (Hak Azasi Manusia) yang tidak tuntas diusut, seperti kasus perburuhan yang disinggung di atas. Kasus Marsinah tidak tuntas, salah satu indikasinya adalah karena campur tangan orang-orang yang memiliki kepentingan. Bila dilihat dari pengaturan politik perburuhan, salah satu poinnya adalah memberikan peluang sekaligus melegitimasi keterlibatan aparat ABRI (Angkatan Bersenjata Republik Indonesia) dalam penyelesaian perselisihan perburuhan. Adanya peraturan tersebut jelas menghambat dalam penyelesaian suatu kasus (Eriyanto, 2000; Ricklefs, 2008; dan Syafa'at, 2008:16).

Isola Pos di Bandung memandang bahwa pemerintah tidak mampu membela rakyatnya pada jalur hukum. Pemerintah juga seakan menutupi hal itu, terlihat dari kata-kata pada tajuk di atas, seperti "keinginan penguasa untuk berdialog". Kalimat itu menunjukan bahwa selama ini pemerintah bersikap menutup diri, arogan, dan cenderung tidak peduli pada

${ }^{5}$ Lihat "Hukum Rakyat Telah Tumbang" dalam Isola Pos, Edisi 8, Tahun II [1993]. Bandung: Penerbit UPM IKIP [Unit Pers Mahasiswa, Institut Keguruan dan Ilmu Pendidikan] Bandung, hlm.4. 
kebutuhan rakyat. Isola Pos di Bandung juga berpandangan bahwa seharusnya pemerintah tidak tebang pilih dalam menegakan proses hukum. Tidak tegaknya hukum di suatu negara, tentu akan menyebabkan kesengsaraan dan penderitaan bagi rakyatnya. Tanpa adanya demokrasi yang berkembang, rakyat seperti berhadapan dengan pemerintahan yang berhati besi (ibidem catatan kaki 5; Firdaus, 1999; dan Eriyanto, 2000).

Secara teoritis dan politik ideal, kekuasaan negara tidak boleh mutlak, tetapi harus dibatasi dengan memberikan jaminan basic human rights. Itu semua ditunjukkan bagi warganya, yang meliputi hak kehidupan, kemerdekaan, dan kepemilikan. Ini bisa terlaksana apabila demokrasi sudah dijalankan dengan baik dan benar (cf Schwarz, 1994; Budiardjo, 2000; dan Markoff, 2002:3).

Seperti Isola Pos di Bandung, Balairung di Yogyakarta juga mengungkapkan hal yang sama mengenai persoalan demokrasi pada salah satu tajuknya, yang ditulis pada tahun 1995. Tajuk tersebut berjudul "Demokrasi: Kekuasaan yang Dibiarkan Bergulir”, yang menegaskan sebagai berikut:

Hakikat sebuah sistem pemerintahan yang mengibarkan panji demokrasi adalah pengakuan terhadap perbedaan-perbedaan, baik kultural, politik, maupun ideologis, yang dimiliki segenap anggotanya. Tanpa keanekaragaman dan penghargaan atasnya, kekuasaan akan menjadi tirani, dalam mana para pemimpin akan menindas kelompokkelompok lain dengan mengatasnamakan hukum, ketertiban, stabilitas, dan tak ketinggalan pembangunan.

Sebuah sistem politik yang menutup diri bagi perbedaan sikap politik, termasuk oposisi politik sekali pun, akan kehilangan relevansinya. Sistem politik akan mengalami krisis legitimasi, kehilangan daya otoritasnya yang substantif; dan dalam situasi seperti ini, pemerintah tak lebih dari kumpulan para bandit yang menyebalkan. ${ }^{6}$

${ }^{6}$ Lihat "Demokrasi: Kekuasaan yang Dibiarkan Bergulir" dalam Balairung, Edisi 22, Tahun IX [1995].
Melalui tajuk di atas, Balairung dari Yogyakarta ingin menyampaikan bahwa pemerintah Indonesia, dalam hal ini pemerintahan Presiden Soeharto, tidak jauh berbeda dengan yang mereka tuliskan. Presiden Soeharto dianggap anti kritik dan tidak menerima atau tidak menyukai keberagaman. Hal itu terbukti dari adanya penyerangan yang dilakukan aparat pemerintah terhadap kantor PDI (Partai Demokrasi Indonesia), penculikan terhadap beberapa aktivis PRD (Partai Rakyat Demokrasi), dan pembredelan pers (ibidem catatan kaki 6; Bhakti et al., 2001; dan Ricklefs, 2008).

Apa yang dituliskan oleh Balairung di Yogyakarta, dalam tajuknya, mengandung makna kebencian kepada pemerintah. Hal itu tercermin dari kalimat "kumpulan para bandit yang menyebalkan". Bandit itu berarti maling, dan Balairung di Yogyakarta menggunakan gaya bahasa yang lebih halus, namun artinya tetap kasar (ibidem catatan kaki 6; Lubis, 1993; dan Siegel, 2000).

Balairung di Yogyakarta berpandangan bahwa seharusnya sebuah pemerintahan yang ideal adalah dengan mau menerima pihak oposisi. Tidak selamanya pihak oposisi berbuat buruk kepada pemerintah, karena bila tidak ada oposisi, maka yang terjadi adalah pemimpin akan lupa diri. Selain itu, Balairung juga ingin menyampaikan bahwa segala hal yang disebutkan oleh pemerintah Orde Baru sebagai bentuk menjaga stabilitas negara, kemajuan ekonomi, ketertiban, dan yang lainnya, hanyalah kedok belaka untuk menyembunyikan keburukan rezim (ibidem catatan kaki 6; Aditjondro, 1998; Sastrosatomo, 1998; dan Winters, 1999).

Pada edisi berikutnya, yakni tahun 1996, Balairung di Yogyakarta menyajikan sebuah karikatur. Sebagaimana nampak dalam gambar 1, karikatur tersebut berkaitan

Yogyakarta: Penerbit UPM UGM [Unit Pers Mahasiswa, Universitas Gadjah Mada], hlm.12. 
dengan PEMILU (Pemilihan Umum), yang akan digelar pada tahun 1997; dan tergambar bahwa posisi Presiden, alias nomor satu, sudah ditempati atau sudah dipesan. Balairung di Yogyakarta memandang bahwa PEMILU akan menjadi sia-sia saja. Pemesannya bisa saja Presiden Soeharto, atau keluarga dan kerabatnya. Balairung di Yogyakarta memandang hal tersebut sebagai kerusakan dalam sebuah sistem pemerintahan. Lebih baik tidak ada PEMILU, dibandingkan ada PEMILU tetapi hasilnya akan melukai hati rakyat dan tidak membuat keadaan menjadi lebih baik.

Tidak hanya Balairung di Yogyakarta, Isola Pos di Bandung juga kembali menyoroti persoalan pemilihan Presiden RI (Republik Indonesia]. Kali ini, Isola Pos

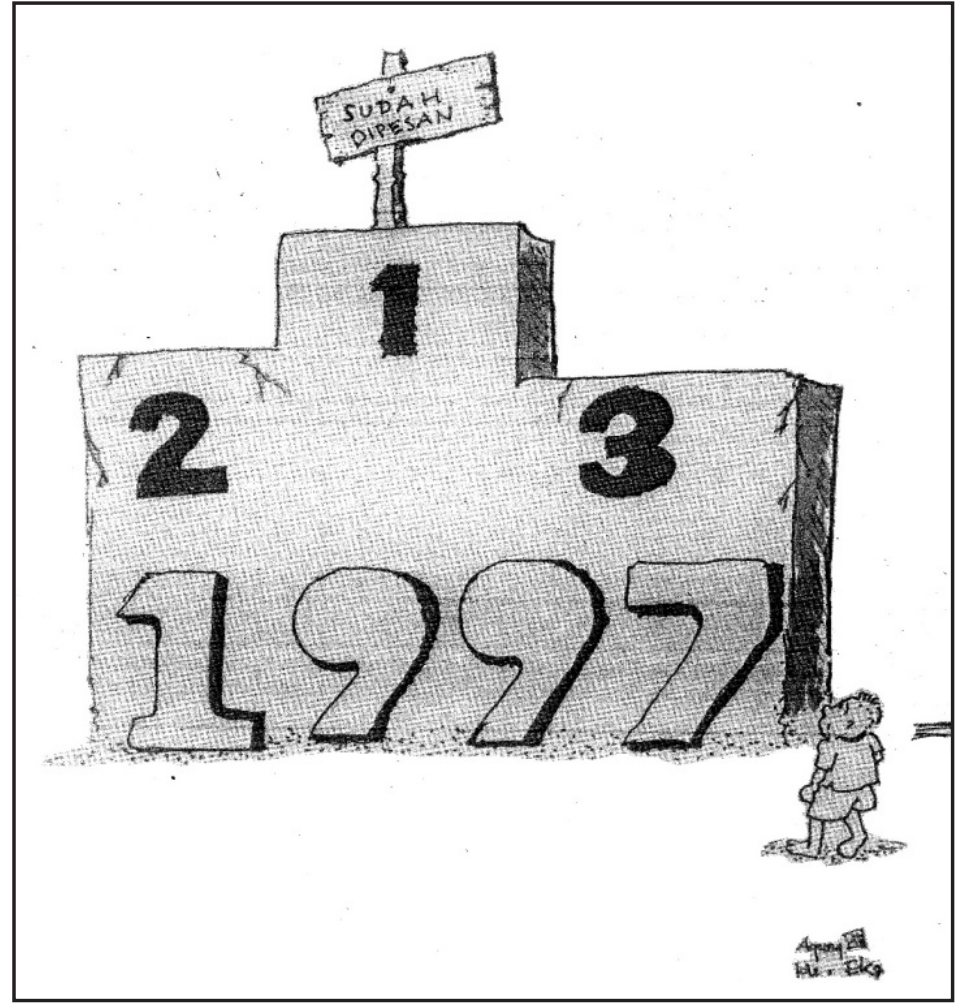

Gambar 1:

“Karikatur” dalam Balairung, Edisi 23, Tahun X [1996], hlm.9. di Bandung mengkritisi melalui karikaturnya yang disajikan pada tahun 1994, dua tahun sebelum Balairung dari Yogyakarta menyoal kepemimpinan Presiden Soeharto. Lihat gambar 2.

Dari karikatur tersebut, Isola Pos di Bandung menggambarkan banyak golongan arus bawah, atau masyarakat biasa, mulai menunjukan diri. Hal itu didasarkan dengan mulai banyaknya masyakarat yang sudah mengerti dan menjadi kelas menengah. Jumlah masyarakat seperti itu mulai banyak, sehingga bisa menentukan suara dalam PEMILU (Pemilihan Umum). Kondisi seperti itu sebagai salah satu dampak dari munculnya LSM (Lembaga Swadaya Masyarakat) atau organisasi-organisasi masyarakat lainnya. Masyarakat memiliki daya tawar terhadap Presiden. Oleh karenanya, Presiden harus memperhitungkan keberadaan anggota masyarakat dari berbagai kelas tersebut.

Isola Pos di Bandung, pada tahun 1994, juga mengeluarkan "Catatan Pojok"

mengenai Presiden RI (Republik Indonesia). Isi "Catatan Pojok" tersebut adalah sebagai berikut:

$$
\begin{aligned}
& \text { "Saya tahu kapan harus mundur", demikian } \\
& \text { Presiden Soeharto. } \\
& \text { Yang dapat membaca isyarat Presiden, dialah } \\
& \text { yang mengganti.? }
\end{aligned}
$$

Dari "Catatan Pojok" tersebut, Isola Pos di Bandung menyiratkan bahwa sebenarnya tidak ada yang tahu kapan Presiden Soeharto akan mundur, sebab yang mengetahui adalah hanya Presiden sendiri. Artinya, Isola Pos di Bandung menyindir bahwa yang nanti akan menjadi Presiden kembali adalah Soeharto sendiri, karena tidak ada persiapan yang jelas siapa yang akan menggantikannya (ibidem catatan kaki 7; Sastrosatomo, 1998;

${ }^{7}$ Lihat "Catatan Pojok" dalam Isola Pos, Edisi 11, Tahun III [1994]. Bandung: Penerbit UPM IKIP [Unit Pers Mahasiswa, Institut Keguruan dan Ilmu Pendidikan] Bandung, hlm.4. 


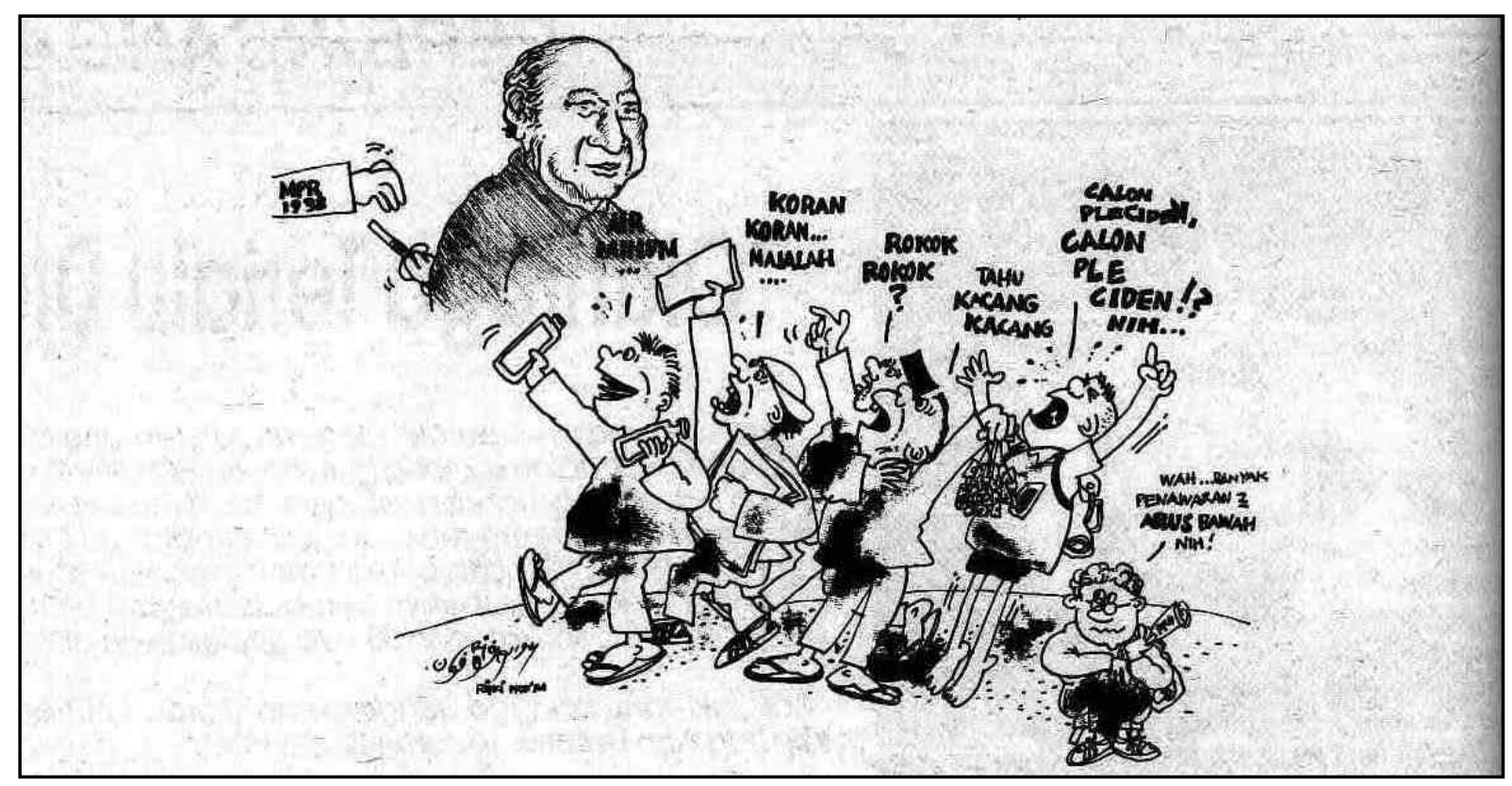

Gambar 2:

“Karikatur” dalam Isola Pos, Edisi 12, Tahun III [1994], hlm.4.

dan Firdaus, 1999).

Tidak hanya Isola Pos di Bandung, Balairung di Yogyakarta juga menyajikan "Catatan Pojok", pada tahun 1995, tentang suksesi kepresidenan. Balairung di Yogyakarta, dengan nada tegas, kembali mengkritik melalui "Catatan Pojok", dengan isi sebagai berikut:

Seorang teman yang habis jalan-jalan dari Parangtritis mengetahui bahwa ada tiga golongan Setan di dunia ini.

Golongan pertama, yaitu Setan yang akan terbakar bila dibacakan ayat kursi. Golongan kedua, yaitu Setan yang akan lari tungganglanggang jika dilempar dengan kursi. Golongan ketiga, yaitu Setan yang takut kehilangan kursi kekuasaannya yang sudah lama ia duduki. ${ }^{8}$

Gaya bahasa "Catatan Pojok" dalam Balairung di Yogyakarta memang tidak ringkas, seperti kebanyakan catatan pojok lainnya (Makah, 1977; dan Suwirta, 2000 dan 2015). Akan tetapi, melalui gaya

${ }^{8}$ Lihat "Catatan Pojok" dalam Balairung, Edisi 22, Tahun IX [1995]. Yogyakarta: Penerbit UPM UGM [Unit Pers Mahasiswa, Universitas Gadjah Mada], hlm.80. bercerita seperti itu memberikan kesan yang khas. Isi dari "Catatan Pojok" dalam Balairung tersebut, dengan nada sinis, menyindir Presiden Soeharto dengan kata-kata yang kasar dan sangat berani. Secara tidak langsung, Balairung sudah mengatakan bahwa Presiden itu adalah "Setan yang takut kehilangan kekuasaan". Kata "Setan" yang digunakan menandakan bahwa Presiden Soeharto diidentikkan dengan seseorang yang mengerikan serta haus akan jabatan (ibidem catatan kaki 8; Aditjondro, 1998; Sastrosatomo, 1998; dan Winters, 1999).

Dari pandangan-pandangan yang telah dikemukakan di atas, antara Isola Pos di Bandung dan Balairung di Yogyakarta memang memiliki persamaan dan perbedaan. Persamaan keduanya adalah banyak mengangkat isu di seputar suksesi Presiden pada tahun 1990-an. Frame yang digunakan juga cenderung sama, termasuk dalam membahas persoalan kelas menengah atau golongan intelektual di Indonesia ( $c f$ Kuntowijoyo, 1985; Latif, 2005; Eriyanto, 2000 dan 2009; dan Mulyana, 2013). 
Namun, dari adanya persamaan dalam pandangan isu politik, ada juga perbedaanperbedaan. Misalnya, dari gaya bahasa yang digunakan. Gaya bahasa yang digunakan oleh Balairung di Yogyakarta lebih tegas dan keras. Selain itu, pandangan-pandangan soal politik lebih banyak dikemukakan dalam tajuk rencana oleh Balairung di Yogyakarta. Artinya, pemberitaan tersebut sebagai laporan utama. Menurut Sunarto et al. (1993), pengambilan isu politik oleh Balairung di Yogyakarta didasarkan atas kenyataan bahwa pada masa itu masih jarang pers mahasiswa yang mengangkat isu politik (Sunarto et al., 1993; dan Asshibbamal, 2011).

Hal itu menjadi sesuatu yang eksotis dan menarik bagi dunia aktivis mahasiswa untuk diperjuangkan. Tujuan akhirnya adalah untuk melakukan suatu perubahan (Damanhuri, 1985; Harahap, 1993; Jaya, 1997; Cula, 1999; dan Arrozy, 2013). ${ }^{9}$ Kampus UGM (Universitas Gadjah Mada) yang ada di Yogyakarta, sebuah kota pedalaman di Jawa, yang pada tahun 19461950, pernah menjadi ibukota Republik Indonesia, mungkin menjadi faktor lain yang menyebabkan "suara mahasiswa" dari kota tersebut sangat tegas, keras, dan lantang kepada penguasa, sebagaimana ditunjukkan pada masa-masa awal revolusi Indonesia (Soemardjan, 1981; dan Suwirta, 2000 dan 2015).

Sedangkan Isola Pos di Bandung lebih banyak membahas isu politik hanya pada rubrik "Catatan Pojok". Dalam kolom tajuktajuk rencananya lebih banyak menyoroti masalah pendidikan. Sebagai sebuah kampus LPTK (Lembaga Pendidikan Tenaga Kependidikan) yang didirikan di Bandung pada tahun 1954, atas prakarsa Menteri Pendidikan, Pengajaran, dan Kebudayaan, Prof. Mr. Muhammad Yamin,

${ }^{9}$ Lihat juga, misalnya, wawancara dengan Sunarto Cipto Harjono, mantan Pemimpin Umum Majalah Balairung di Yogyakarta, wawancara dilakukan via telepon, pada tanggal 23 Juli 2014 dan dididik untuk menjadi Guru dan Tenaga Pendidik yang dedikatif dan profesional, "suara mahasiswa" dari IKIP (Institut Keguruan dan Ilmu Pendidikan), yang pada tahun 2000 menjadi UPI (Universitas Pendidikan Indonesia), memang tergolong lunak, halus, sopan, tapi tetap penuh dengan sindiran dan sarkasme yang tajam (Zulkabir \& Suwirta eds., 2010; dan Sirat, 2011).

\section{KESIMPULAN ${ }^{10}$}

Pers mahasiswa merupakan alternatif pemberitaan pada masa Orde Baru (19661998), mengingat posisi pers umum yang dengan mudah dicabut izin terbitnya. Memang, pers mahasiswa juga rawan akan pembredelan. Akan tetapi, pers mahasiwa selalu bisa berupaya untuk tetap survive dan menghindari pencabutan izin terbit. Sifatnya yang berbeda dengan pers umum, menjadi ciri khas tersendiri bagi pers mahasiswa. Terkadang pers mahasiswa dianggap amatir atau tidak profesional, mengingat persoalanpersoalan klasik yang selalu mendera. Misalnya, persoalan kurangnya dana atau kurangnya anggota, yang menyebabkan periodesasi terbit menjadi tidak teratur: kadang terbit, kadang tidak.

Namun, hal itu sebaiknya tidak dipandang sebelah mata bagi pers mahasiswa. Pers mahasiswa tidak berbicara mengenai periodesasi terbit ataupun jumlah pembaca, melainkan ideologi atau pemikiran yang disajikan dan disampaikan kepada khalayak pembaca. Pemikiran apa yang dimiliki oleh pers mahasiswa untuk menjadi

\footnotetext{
${ }^{10}$ Sebuah Pengakuan: Artikel ini, sebelum dikemaskini dan disempurnakan dalam bentuknya sekarang, merupakan Ringkasan Skripsi Sarjana dari Penulis I (Nisa Rizkiah), yang dibimbing oleh Penulis II (Andi Suwirta) dan Penulis III (Encep Supriatna), serta diselesaikan dalam Ujian Sidang di Jurusan Pendidikan Sejarah FPIPS UPI (Fakultas Pendidikan Ilmu Pengetahuan Sosial, Universitas Pendidikan Indonesia) di Bandung, pada bulan Agustus 2014. Kami mengucapkan terima kasih kepada semua pihak yang telah mendorong dan membantu penyelesaian artikel ini. Walaupun begitu, semua isi dan interpretasi dalam artikel ini, sepenuhnya menjadi tanggung jawab akademik kami bertiga.
} 
jembatan menuju proses demokratisasi, serta kehidupan dalam bermasyarakat, berbangsa, dan bernegara yang lebih baik dan maju.

Pers mahasiswa di Indonesia sudah ada sejak masa Orde Lama (1950-1966), tetapi setiap zaman tentu memiliki ceritanya sendiri. Dalam kajian ini, yang diambil adalah pers mahasiswa pada tahun 1990-an, atau masa Orde Baru. Pers di masa Orde Baru tidak bebas dan banyak larangan dalam isi pemberitaan. Begitu pula yang dihadapi oleh pers mahasiswa; sebagai pers, mereka dihadapkan pada isu bredel. Sedangkan sebagai sebuah gerakan mahasiswa, mereka dihadapkan pada berbagai kebijakan yang mungkin saja akan mematikan denyut nadi sebuah gerakan mahasiswa. Selama tahun 1990-an, misalnya, badai yang menerpa pers mahasiswa begitu banyak, dari pembredelan beberapa pers mahasiswa dan kebijakan-kebijakan yang merugikan bagi perkembangan pers mahasiswa.

Kajian ini mengambil dua pers mahasiswa, yang masing-masing berada di Bandung, Jawa Barat, dan Yogyakarta, Jawa Tengah. Pers mahasiswa yang dipilih adalah Isola Pos di IKIP (Institut Keguruan Ilmu Pendidikan) Bandung dan Balairung di UGM (Universitas Gadjah Mada) Yogyakarta. Dua pers mahasiswa itu lahir dan berkembang pada awal 1990-an. Keduanya menjadi saksi sejarah tentang bagaimana sebuah pemerintah yang otoriter memimpin negeri ini. Kedua pers mahasiswa itu juga menjadi saksi bagaimana mahasiswa dan elemen masyarakat bersatu untuk meurunkan Presiden Soeharto, yang sudah berkuasa selama 32 tahun.

Pola gerakan yang diambil oleh pers mahasiswa tentu berbeda dengan gerakan mahasiswa pada umumnya. Pers mahasiswa bergerak melalui media yang mereka miliki. Mereka menuangkan gagasan-gagasan melalui tulisan, mengecam segala bentuk ketidakadilan, dan mereka juga kerap menyatakan pandangan dan kritik sosial bila pemerintah berada pada jalur yang tidak benar. Dari hasil analisis yang didasarkan kepada sajian tajuk rencana, catatan pojok, karikatur, dan bahkan surat pembaca, kiranya bisa disimpulkan beberapa hal, sebagai berikut:

Pertama, pers mahasiswa Indonesia pada periode tahun 1990-an, khususnya dari tahun 1991-1998, mulai kembali menunjukan eksistensi dirinya, setelah tertidur panjang akibat kebijakan NKK/ BKK (Normalisasi Kehidupan Kampus / Badan Koordinasi Kampus). Pers mahasiswa pada periode 1990 -an pun mulai melakukan berbagai konsolidasi untuk menguatkan jaringan dan gerakan yang sedang dibangun. Namun, para pegiat pers mahasiswa tetap harus menghadapi berbagai kebijakan yang dianggap sebagai pengganti NKK/BKK, seperti Wawasan Almamater, yang digagas oleh Menteri Pendidikan dan Kebudayaan, dengan maksud untuk tetap bisa mengendalikan kehidupan mahasiswa.

Namun, pers mahasiswa tetap melakukan perlawanan. Mereka menganggap bahwa yang dijalankan oleh pemerintah sudah tidak sesuai lagi dengan kehendak zaman dan aspirasi rakyat banyak. Pemerintah, pada tahun 1990-an, telah banyak melakukan KKN (Korupsi, Kolusi, Nepotisme) yang mencolok mata; dan itu tentu saja merugikan masyarakat banyak. Kondisi tersebut terus dituntut dan digugat oleh pers mahasiswa pada periode 1990 -an. Para pegiat pers mahasiswa tidak pantang menyerah, walaupun dihadapkan pada berbagai kondisi yang sulit, salah satunya adalah masalah pembredelan. Tetapi, hal itu tidak membuat pers mahasiswa mundur; justru sebaliknya, mereka tumbuh makin subur. Pers mahasiswa pada periode 1990an memiliki tujuan untuk melakukan suatu perubahan terhadap sistem pemerintahan yang ada. Melalui caranya sendiri, pers mahasiswa bersatu dengan gerakan mahasiswa pada umumnya.

Kedua, baik Isola Pos di Bandung maupun Balairung di Yogyakarta memiliki 
perbedaan dan persamaan dalam porsi news and views atau pemberitaan dan pandangan. Dalam konteks ini, Isola Pos di Bandung lebih banyak membicarakan persoalan pendidikan, dibandingkan persolan politik. Hampir semua tajuk rencana dan karikaturnya didominasi oleh isu-su di sekitar dunia pendidikan. Porsi untuk gerakan mahasiswa dan politik, tidak terlalu banyak. Selain itu, pada "Catatan Pojok"nya memang Isola Pos di Bandung banyak membahas isu politik. Namun, "Catatan Pojok" dalam Isola Pos di Bandung, posisinya tidak sentral seperti tajuk rencana dan karikatur. "Catatan Pojok" hanya berupa sindiran-sindiran yang halus, cerdas, dan tidak langsung, bukan seperti tajuk rencana yang merupakan sikap dari redaksi. Pada beberapa edisi, Isola Pos di Bandung memang membahas persoalan politik nasional, akan tetapi persoalan pendidikan menjadi isu yang dominan dan kerap diangkat untuk disajikan kepada khalayak pembaca.

Alasan Isola Pos di Bandung lebih memilih isu pendidikan, karena berpandangan bahwa pendidikan adalah sesuatu yang penting bagi kemajuan dan kesejahteraan sebuah negara-bangsa. Pendidikan harus dijalankan dengan benar, tidak boleh dipolitisasi, dan harus sejalan dengan cita-cita para pendiri bangsa. Pendidikan juga memilik dampak yang besar bagi kualitas SDM (Sumber Daya Manusia) pada suatu negara-bangsa. Selain itu, Isola Pos di Bandung juga lahir dalam sebuah PT (Perguruan Tinggi) yang berkecimpung dalam dunia pendidikan. Karena itu, Isola Pos di Bandung merasa memiliki tanggung jawab yang besar untuk menyampaikan dan mengkritisi kebijakankebijakan dalam bidang pendidikan.

Sedangkan Balairung di Yogyakarta, dalam pemberitaannya pada tahun 1990an, lebih banyak porsi untuk berita-berita politik. Misalnya, isu tentang KKN yang dilakukan oleh pemerintahan Presiden
Soeharto. Dalam karikatur dan "Catatan Pojok"'-nya pun, Balairung di Yogyakarta, banyak didominasi oleh isu-isu politik. Dalam beberapa "Catatan Pojok" memang ditemui pula isu tentang pendidikan, tetapi porsinya tidak terlalu besar. Isu pendidikan yang diambil pun lebih didominasi oleh gerakan mahasiswa dan kebijakan pendidikan secara nasional.

Alasan Balairung di Yogyakarta lebih memilih isu politik sebagai pemberitaan utama, karena berpandangan bahwa isuisu politik adalah sesuatu yang eksotis dan menarik banyak pihak pada zamannya. Balairung di Yogyakarta memandang bahwa mahasiswa harus peduli dengan politik, karena hal itu adalah salah satu cara untuk melakukan sebuah perubahan pada sistem sosial dan politik yang ada di Indonesia. Bagi redaksi Balairung di Yogyakarta, mahasiswa harus menjadi aktor dan motor dalam perubahan sosial-politik suatu negara-bangsa.

Dari segi bahasa yang digunakan, Isola Pos di Bandung lebih meramu bahasa yang lugas tapi tetap sopan, dan apa adanya. Berbeda dengan Balairung di Yogyakarta yang meramu bahasanya menggunakan jurnalisme sastrawi, yaitu cara menulis dengan gaya bercerita dan mengalir, tapi tegas dan keras tanpa tedeng aling-aling. Sepintas, bila membaca tajuk rencana milik Balairung di Yogyakarta, tidak akan merasa bahwa itu adalah sebuah tajuk rencana, karena selain mengandung unsur sastrawi, unsur intelektualnya begitu ketara. Hal ini juga terlihat dari pengutipan pendapat beberapa filsuf atau para pemikir-pemikir dari luar, yang digunakan dalam tajuk rencananya.

Selain tajuk rencana dan karikatur, cara panulisan "Catatan Pojok" dalam Balairung di Yogyakarta berbeda dengan Isola Pos di Bandung. Pada umumnya, Isola Pos di Bandung menyajikan "Catatan Pojok" yang singkat dan jelas, atau seperti pada umumnya catatan pojok dalam sebuah surat 
kabar. Namun, Balairung di Yogyakarta menyajikan "Catatan Pojok"-nya dengan gaya bercerita, sehingga lebih panjang dan tidak nampak seperti sebuah "Catatan Pojok" pada umumnya dalam sebuah surat kabar.

Meskipun dari segmentasi berita yang diambil berbeda, akan tetapi ada benang merah di antara keduanya. Baik Isola Pos di Bandung maupun Balairung di Yogyakarta, mereka sama-sama membahas soal gerakan mahasiswa dan isu-isu yang berwawasan nasional, walaupun menggunakan frame yang berbeda. Kedua pers mahasiswa itu memiliki ciri khasnya masing-masing. Ciri khas itu dilatarbelakangi oleh di mana pers mahasiswa berada, tumbuh, dan berkembang dalam sebuah PT yang punya jatidiri masing-masing.

Namun, meskipun berbeda dalam fokus atau framing pemberitaan, keduanya samasama memiliki tujuan yang mulia, yakni menyuarakan perubahan untuk Indonesia ke arah yang lebih baik, dengan melakukan perlawanan terhadap suatu rezim yang dianggap menyimpang dari kebijakan untuk kemajuan dan kesejahteraan sebuah negarabangsa. ${ }^{11}$

\section{Referensi}

Abrar, Ana Nadhya. (1992). Pers Mahasiswa dan Permasalahan Operasionalisasinya. Yogyakarta: Penerbit Liberty.

Aditjondro, George Junus. (1998). Dari Soeharto ke Habibie: Guru Kencing Berdiri, Murid Kencing Berlari, Kedua Puncak Korupsi, Kolusi, dan

\footnotetext{
${ }^{11}$ Pernyataan: Kami menyatakan bahwa artikel ini, beserta seluruh isinya, adalah benar-benar karya kami sendiri dan tidak melakukan penjiplakan atau pengutipan dengan cara-cara yang tidak sesuai dengan etika keilmuan yang berlaku dalam masyarakat keilmuan. Artikel ini belum pernah dipublikasikan dalam jurnal nasional maupun internasional atau dalam prosiding manapun. Atas pernyataan ini, kami siap menanggung resiko atau sanksi yang dijatuhkan kepada kami apabila kemudian ditemukan adanya pelanggaran terhadap etika keilmuan dalam karya kami ini, atau ada klaim dari pihak lain terhadap keaslian karya ini.
}

Nepotisme Rezim Orde Baru. Jakarta: Penerbit MIK [Masyarakat Indonesia untuk Kemanusiaan]. Ahmad, Abdul Razaq \& Andi Suwirta. (2007). Sejarah dan Pendidikan Sejarah: Perspektif Malaysia dan Indonesia. Bandung: Historia Utama Pers.

Ali, Denny Januar. (2006). Gerakan Mahasiswa dan Politik Kaum Muda Era 1980-an. Yogyakarta: Penerbit LKiS.

Arismunandar, S. (2005). Bergerak! Peran Pers Mahasiswa dalam Penumbangan Rezim Soeharto. Yogyakarta: Genta Press.

Arrozy, Ahmad Mujahid. (2013). “Antara Jakarta dan Yogyakarta: Gerakan Mahasiswa Islam pada Masa Orde Baru". Skripsi Sarjana Tidak Diterbitkan. Yogyakarta: Jurusan Sejarah FIB UGM [Fakultas Ilmu Budaya, Universitas Gadjah Mada]. Tersedia secara online juga di: https://www.researchgate. net/publication/316430580 [diakses di Bandung, Indonesia: 28 Oktober 2017].

Aspinall, Edward. (1999). "The Indonesia Student Uprising 1998" in Arief Budiman, Barbara Hatley \& Damien Kingsbury [eds]. Reformasi: Crisis and Change in Indonesia. Clayton: Monash Institute.

Asshibbamal, Lubabun Ni'am S. (2011). "Balairung dan Sejarah yang Tercacah" dalam Journal of Community Development, Vol.44/XXIII, hlm.182-188.

Bhakti, Ikrar Nusa et al. (2001). Militer dan Politik Kekerasan Orde Baru: Soeharto di Belakang Peristiwa 27 Juli. Bandung: Penerbit Zaman.

Budiardjo, Miriam. (2000). Dasar-dasar Ilmu Politik. Jakarta: PT Gramedia.

“Catatan Pojok" dalam Balairung, Edisi 22, Tahun IX [1995]. Yogyakarta: Penerbit UPM UGM [Unit Pers Mahasiswa, Universitas Gadjah Mada], hlm.80.

"Catatan Pojok" dalam Isola Pos, Edisi 11, Tahun III [1994]. Bandung: Penerbit UPM IKIP [Unit Pers Mahasiswa, Institut Keguruan dan Ilmu Pendidikan] Bandung, hlm.4.

Cula, Adi Suryadi. (1999). Patah Tumbuh, Hilang Berganti: Sketsa Gerakan Mahasiswa dalam Politik dan Sejarah Indonesia, 1908-1998. Jakarta: PT Raja Grafindo.

Damanhuri, Didin S. (1985). Menerobos Krisis: Renungan Masalah Kemahasiswaan, Intelektual, dan Perguruan Tinggi. Jakarta: Inti Sarana Aksara.

"Demokrasi: Kekuasaan yang Dibiarkan Bergulir" dalam Balairung, Edisi 22, Tahun IX [1995]. Yogyakarta: Penerbit UPM UGM [Unit Pers Mahasiswa, Universitas Gadjah Mada], hlm.12.

Dhakidae, D. (1977). "Penerbitan Kampus: Cagar Alam Kebebasan Pers" dalam Majalah Prisma, Edisi 10 [Oktober]. 
Dipopramono, Abdul Hamid. (1989). "Pers Mahasiswa dan Unjuk Rasa" dalam Majalah Komponen, Nomor 1, Tahun I.

Elson, R.E. (2005). Suharto: Sebuah Biografi Politik. Jakarta: Pustaka Minda Utama, Terjemahan.

Eriyanto. (2000). Kekuasaan Otoriter dari Gerakan Penindasan menuju Politik Hegemoni: Studi atas Pidato-pidato Politik Soeharto. Yogyakarta: Penerbit INSIST.

Eriyanto. (2009). Analisis Framing: Konstruksi, Ideologi, dan Politik Media. Yogyakarta: Penerbit LKiS.

Fadhly, Fachrus Zaman [ed]. (1999). Mahasiswa Menggugat: Potret Gerakan Mahasiswa Indonesia 1998. Bandung: Pustaka Hidayah.

Fathoni, Mohammad et al. (2012). Menapak Jejak Perhimpunan Pers Mahasiswa Indonesia. Depok: Komodo Books.

Firdaus, K.H.A.N. (1999). Dosa-dosa Politik Orde Lama dan Orde Baru yang Tidak Boleh Berulang lagi di Era Reformasi. Jakarta: Pustaka AlKautsar. Tersedia secara online juga di: https:// goyimstrikeback.files.wordpress.com/2008/12/ dosa-dosa-politik.pdf [diakses di Bandung, Indonesia: 28 Oktober 2017].

Freire, Paulo. (1999). Politik Pendidikan, Kebudayaan, Kekuasaan, dan Pembebasan. Yogyakarta: Pustaka Pelajar, Terjemahan.

Gunawan, R. et al. (2009). Menyulut Lahan Kering: Perlawanan Gerakan Mahasiswa 1990-an. Jakarta: Penerbit Spasi \& VHR Book.

Harahap, Krisna. (2006). Pasang-Surut Kemerdekaan Pers di Indonesia. Bandung: Penerbit Grafiti.

Harahap, Muchtar E. (1993). Mahasiswa dalam Politik. Jakarta: Penerbit NSEAS.

Haris, Syamsuddin \& Riza Sihbudi [eds]. (1995). Menelaah Kembali Format Politik Orde Baru. Jakarta: Yayasan Insan Politika.

Hatta, Mohamad. (1953). Kumpulan Karangan. Djakarta: Penerbitan dan Balai Buku Indonesia.

Hefner, Robert W. (1993). "Islam, State, and Civil Society: ICMI and the Struggle for the Indonesian Middle Class" in Indonesia, Volume 56 [October]. Ithaca, New York: Cornell University, pp.1-36.

Hidayat, N. (1992). "12 Tahun Kemudian” dalam Balairung, Edisi 15, Tahun VII. Yogyakarta: Penerbit UPM UGM [Unit Pers Mahasiswa, Universitas Gadjah Mada], hlm.8.

Hill, David T. (2011). Pers di Masa Orde Baru. Jakarta: Penerbit YOI [Yayasan Obor Indonesia], Terjemahan.

"Hukum Rakyat Telah Tumbang" dalam Isola Pos, Edisi 8, Tahun II [1993]. Bandung: Penerbit UPM IKIP [Unit Pers Mahasiswa, Institut Keguruan dan Ilmu Pendidikan] Bandung, hlm.4.

Ismaun. (2005). Pengantar Ilmu Sejarah. Bandung:
Historia Utama Press.

Jaya, Indra. (1997). “Koreksi demi Koreksi: Pergerakan Mahasiswa Indonesia Pasca MALARI sampai Penolakan NKK/BKK, 1974-1980". Skripsi Sarjana Tidak Diterbitkan. Depok: Program Studi Sejarah FIPB UI [Fakultas Ilmu Pengetahuan Budaya, Universitas Indonesia].

Jenkins, David. (2010). Soeharto dan Barisan Jenderal Orde Baru: Rezim Militer Indonesia, 1973-1983. Depok: Komunitas Bambu, Terjemahan.

Kaisiepo, M. (1978). "Sistem Pendidikan di Perguruan Tinggi dalam Kacamata seorang Mahasiswa" dalam Majalah Prisma, Edisi Desember.

"Karikatur" dalam Balairung, Edisi 23, Tahun X [1996]. Yogyakarta: Penerbit UPM UGM [Unit Pers Mahasiswa, Universitas Gadjah Mada], hlm.9.

Kartodiwirio, Sudarsono Katam. (2006). Bandung Kilas Peristiwa di Mata Filatelis: Sebuah Wisata Sejarah. Bandung: Kiblat Buku Utama.

Kresna, Mawa. (2016). "Membredel Pers Mahasiswa". Tersedia secara online di: https:// tirto.id/membredel-pers-mahasiswa-b5ka [diakses di Bandung, Indonesia: 28 Oktober 2017].

Kuntowijoyo. (1985). "Muslim Kelas Menengah Indonesia dalam Mencari Identitas, 1910-1950" dalam majalah Prisma, Edisi 11. Jakarta: Penerbit LP3ES.

Kuntowijoyo. (2003). Metodologi Sejarah. Yogyakarta: Tiara Wacana Yogya.

Latif, Yudi. (2005). Inteligensia Muslim dan Kuasa: Inteligensia Muslim Indonesia Abad ke-20. Bandung: Penerbit Mizan.

Lubis, Mochtar. (1993). Bromocorah: Dua Belas Cerita Pendek. Jakarta: Penerbit YOI [Yayasan Obor Indonesia].

Luftiany, Trina \& Imam Santosa. (2014). "Bandoeng Tempo Doeloe" dalam Jurnal Tingkat Sarjana: Bidang Senirupa dan Desain. Tersedia secara online juga di: file:///C:/Users/ acer/Downloads/67-204-1-PB.pdf [diakses di Bandung, Indonesia: 28 Oktober 2017].

Mahasin, Aswab [ed]. (1984). Cendekiawan dan Politik. Jakarta: Penerbit LP3ES.

Makah, M. (1977). "Pojok sebagai Penyalur Kritik" dalam majalah Prisma, No.10 [Oktober].

Mardiansyah, D. (2007). "Dari Oral Pos ke Isola Pos" dalam Isola Pos, Edisi 43, Tahun XVII. Bandung: Penerbit UPM UPI [Unit Pers Mahasiswa, Universitas Pendidikan Indonesia].

Markoff, John. (2002). Gelombang Demokrasi Dunia. Yogyakarta: Pustaka Pelajar, Terjemahan.

Matulessy, Andik. (2005). Mahasiswa \& Gerakan Sosial. Surabaya: Penerbit Srikandi.

Mulyana, Dedy. (2013). Metodologi Penelitian 
Kualitatif: Paradigma Baru Ilmu Komunikasi dan Ilmu Sosial Lainnya. Bandung: PT Remaja Rosdakarya.

Muntaha, D. (1999). "Kumparan Api yang Hampir Padam" dalam Majalah Civitas, Edisi 36.

Parera, F.M. (1977). "Surat Pembaca: Sebuah Bentuk Kritik Sosial" dalam majalah Prisma, No.10 [Oktober].

Poesponegoro, Marwati Djoened \& Nugroho Notosusanto [eds]. (1993). Sejarah Nasional Indonesia, Jilid VI. Jakarta: Balai Pustaka.

Pour, Julius. (2007). Benny: Tragedi Seorang Loyalis. Jakarta: Kata Hasta Pustaka.

Pratiwi, Rhesa Zuhriya Briyan. (2013). "Persepsi Mahasiswa terhadap Pers Mahasiswa: Studi Deskriptif Kualitatif mengenai Persepsi Mahasiswa terhadap Eksistensi Pers Mahasiswa di Universitas Sebelas Maret, Surakarta”. Skripsi Sarjana Tidak Diterbitkan. Surakarta: Program Studi Ilmu Komunikasi FISIP UNS [Fakultas Ilmu Sosial dan Ilmu Politik, Universitas Sebelas Maret]. Tersedia secara online juga di: https:// eprints.uns.ac.id/12415/1/328482511201306011 unprotected.pdf [diakses di Kota Bandung, Indonesia: 9 Oktober 2017].

Purwanto, Bambang, Djoko Suryo \& Soegijanto Padmo [eds]. (1999). Dari Revolusi ke Reformasi: 50 Tahun Universitas Gadjah Mada. Yogyakarta: Pusat Studi Pariwisata UGM [Universitas Gadjah Mada].

Puthut, E.A. (2015). Menanam Padi di Langit. Yogyakarta: EA Books. Tersedia secara online juga di: https://sumbersejarah.files.wordpress. com/2016/07/book-puthut [diakses di Bandung, Indonesia: 28 Oktober 2017].

Raillon, F. (1985). Politik dan Ideologi Mahasiswa Indonesia: Pembentukan dan Konsolidasi Orde Baru, 1966-1974. Jakarta: Penerbit LP3ES, Terjemahan.

Ricklefs, M.C. (2008). Sejarah Indonesia Modern, 1200-2008. Jakarta: Penerbit Serambi.

Rumagit, Stev Koresy. (2013). "Kekerasan dan Diskriminasi antar Umat Beragama di Indonesia" dalam Lex Administratum, Vol.1, No.2 [Januari - Maret]. Tersedia secara online di: https:// ejournal.unsrat.ac.id/index.php/administratum/ article/viewFile/3016/2561 [diakses di Bandung, Indonesia: 28 Oktober 2017].

Said, Edward W. (1998). Peran Intelektual: Kuliahkuliah Reith Tahun 1993. Jakarta: Penerbit YOI [Yayasan Obor Indonesia], Terjemahan.

Saidi, Ridwan. (1989). Mahasiswa dan Lingkaran Politik. Jakarta: LPM [Lembaga Pers Mahasiswa] Mapussy Indonesia.

Sanit, Arbi. (1999). Pergolakan Melawan Kekuasaan. Yogyakarta: Insist Press.
Saputra, Angga Apip Wahyu. (2012). "Peranan Mahasiswa Yogyakarta dalam Perjuangan Reformasi di Indonesia (1998)". Skripsi Sarjana Tidak Diterbitkan. Yogyakarta: Program Studi Pendidikan Sejarah FIS UNY [Fakultas Ilmu Sosial, Universitas Negeri Yogyakarta]. Tersedia secara online juga di: http://eprints.uny.ac.id/21766/2/ Angga \%20Apip\%20WS.pdf [diakses di Kota Bandung, Indonesia: 9 Oktober 2017].

Sastrosatomo, Soebadio. (1998). Politik Dosomuko Rezim Orde Baru: Rapuh dan Sengsarakan Rakyat. Jakarta: Pusat Dokumentasi Politik "Guntur 49".

Schwarz, Adam. (1994). A Nation in Waiting: Indonesia in the 1990's. St. Leonards, NSW: Allen \& Unwin Pty Ltd.

"Sebuah Perjalanan Panjang Unit Penerbitan Mahasiswa IKIP Bandung: Mengapa Musti Ada?". Artikel Tanpa Nama Pengarang, Tidak Diterbitkan. Bandung: UPM UPI [Unit Pers Mahasiswa, Universitas Pendidikan Indonesia], 2004.

Sedayu, A. (2004). Kisah Sejarah Perhimpunan Pers Mahasiswa Indonesia (PPMI). Jakarta: Arsip PPMI.

Sen, K. \& D.T. Hill. (2001). Media, Budaya, dan Politik di Indonesia. Jakarta: Penerbit ISAI [Institut Studi Arus Informasi], Terjemahan.

Siegel, James T. (2000). Penjahat Gaya (Orde) Baru: Eksplorasi Politik dan Kriminalitas. Yogyakarta: Penerbit LKiS, Terjemahan.

Sirat, Rudini. (2011). Dari Isola ke Bumi Siliwangi. Depok: Komodo Books.

Siregar, Amir Effendi. (1983). Pers Mahasiswa: Patah Tumbuh, Hilang Berganti. Jakarta: Karya Unipress.

Sjamsuddin, Helius. (2007). Metodologi Sejarah. Yogyakarta: Penerbit Ombak.

Soeharto. (1989). Pikiran, Ucapan, dan Tindakan Saya: Otobiografi seperti Dipaparkan kepada $G$. Dwipayana dan Ramadhan K.H. Jakarta: PT Citra Lamtoro Gung Persada.

Soemardjan, Selo. (1981). Perubahan Sosial di Yogyakarta. Yogyakarta: Gadjah Mada University Press, Terjemahan.

Soemardjan, Selo [ed]. (1998). Kisah Perjuangan Reformasi. Jakarta: Pustaka Sinar Harapan.

Stake, Robert E. (1994). "Case Studies” in Norman K. Denzin \& Yvonna S. Lincoln [eds]. Handbook of Qualitative Research. Thousand Oaks, California: SAGE Publications, Inc.

Sudibyo, Agus. (2001). Politik Media dan Partarungan Wacana. Yogyakarta: Penerbit LKiS.

Sudarta, G.M. (2007). 40 Tahun Oom Pasikom: Peristiwa dalam Kartun, Tahun 1967-2007. Jakarta: Penerbit Buku Kompas.

Suganda, Her. (2007). Jendela Bandung: Pengalaman Bersama Kompas. Jakarta: Penerbit 
Buku Kompas

Suharsih \& I.K. Mahendra. (2007). Bergerak Bersama Rakyat: Sejarah Gerakan Mahasiswa dan Perubahan Sosial di Indonesia. Yogyakarta: Resist Book.

Sulastomo. (2008). Hari-hari yang Panjang: Transisi Orde Lama ke Orde Baru. Jakarta: Penerbit Kompas.

Sunarto et al. (1993). "PPMI: Kalau Berani, Jalan Terus!" dalam Balairung, Edisi 17. Yogyakarta: Penerbit UPM UGM [Unit Pers Mahasiswa, Universitas Gadjah Mada], hlm.33.

Supriyanto, D. (1998). Perlawanan Pers Mahasiswa: Protes Sepanjang NKK/BKK. Jakarta: Pustaka Sinar Harapan.

Supriyanto, Henri. (1986). Pengantar Praktek Kewartawanan Pers Kampus dan Majalah Sekolah. Bandung: Penerbit Angkasa.

"Surat Keputusan Pembantu Rektor III IKIP Bandung tentang Pembentukan UPM IKIP Bandung, Tanggal 21 Desember 1987'. Arsip Tidak Diterbitkan dan Salinan Copy, ada pada Penulis.

Surdiasis, F. (1995). "Kekuasaan yang Dibiarkan Bergulir" dalam majalah Balairung, Edisi 22, Tahun IX. Yogyakarta: Penerbit UPM UGM [Unit Pers Mahasiswa, Universitas Gadjah Mada], hlm.12.

Suryadi, A.R. (1991). "Panggung-panggung Mitologi dalam Hegemoni Negara: Gerakan Mahasiswa di Bawah Orde Baru" dalam Prisma, No.10 [Oktober]. Jakarta: Penerbit LP3ES.

Suwirta, Andi. (2000). Suara dari Dua Kota: Revolusi Indonesia dalam Pandangan Surat Kabar Merdeka di Jakarta dan Kedaulatan Rakjat di Yogyakarta, 1945-1947. Jakarta: PN Balai Pustaka.

Suwirta, Andi. (2015). Revolusi Indonesia dalam News \& Views: Sebuah Antologi Sejarah. Yogyakarta: Penerbit Ombak.

Suwirta, Andi. (2017). "Pers dan Kritik Sosial pada Masa Orde Baru: Kasus Peristiwa Tanjung Priok Tahun 1984 dalam Pandangan Surat Kabar Merdeka dan Kompas di Jakarta" dalam INSANCITA: Journal of Islamic Studies in Indonesia and Southeast Asia, Volume 2(2), August, pp.101-122. Bandung, Indonesia: Minda Masagi Press owned by ASPENSI, ISSN 2443-1776.

Syafa'at, A. (2008). Gerakan Buruh dan Pemenuhan Hak Dasarnya: Strategi Buruh Dalam Melakukan Advokasi. Malang: In-Trans Publishing.

Syahriah, Fahmi. (2009). "Peran Politik Pers
Mahasiswa Tahun 1998-2008: Studi pada Lembaga Pers Mahasiswa di Kota Malang”. Tersedia secara online di: https://core.ac.uk/ download/pdf/12148076.pdf [diakses di Kota Bandung, Indonesia: 9 Oktober 2017].

Syuaib, Fauzie. (1987). “Organisasi Kemahasiswaan: Upaya Mencari Bentuk Baru” dalam Majalah 0 o. Jakarta: 6 Juni.

Uhlin, A. (1998). Oposisi Berserak: Arus Demokratisasi Gelombang Ketiga Di Indonesia. Bandung: Penerbit Mizan.

"Unit Pers Mahasiswa UPI: The Brief History". Artikel Tanpa Nama Pengarang, Tidak Diterbitkan. Bandung: UPM UPI [Unit Pers Mahasiswa, Universitas Pendidikan Indonesia], 2003.

UPI [Universitas Pendidikan Indonesia]. (2013). Pedoman Penulisan Karya Ilmiah. Bandung: UPI Press.

Utomo, P.W. (2013). Pers Mahasiswa Melawan Komersialisasi Pendidikan. Yogyakarta: Indie Book Corner.

Wawancara dengan Agus R. Sarjono, penggagas dan pendiri Kelompok Studi Lingkar dan Isola Pos, di Depok, Jawa Barat, Indonesia, wawancara dilakukan oleh Rudini Sirat, pada tanggal 1 Agustus 2009.

Wawancara dengan Kelik Supriyanto, mantan Staf Redaksi Majalah Balairung, di Yogyakarta, Indonesia, pada tanggal 26 Mei 2014.

Wawancara dengan Sunarto Cipto Harjono, mantan Pemimpin Umum Majalah Balairung di Yogyakarta, wawancara dilakukan via telepon, pada tanggal 23 Juli 2014.

Wawancara via e-mail dengan Dwi Joko Widiyanto, mantan Pemimpin Redaksi Isola Pos, pada tanggal 27 Juni 2014.

Widjojo, S.M. et al. (1999). Penakluk Rezim Orde Baru: Gerakan Mahasiswa 1998. Jakarta: Pustaka Sinar Harapan.

Widjojo, S.M. \& M. Noorsalim. (2004). Bahasa Negara Versus Bahasa Gerakan Mahasiswa. Jakarta: LIPI [Lembaga Ilmu Pengetahuan Indonesia] Press.

Winters, Jeffrey A. (1999). Dosa-dosa Politik Orde Baru. Jakarta: Penerbit Djambatan, Terjemahan.

Zulkabir \& Andi Suwirta [eds]. (2010). Pentingnya Pendidikan Guru Tingkat Universitas: Pemikiran Pendidikan dari Mas Sadarjoen Siswomartojo hingga Sunaryo Kartadinata, 1954-2015. Bandung: UPI [Universitas Pendidikan Indonesia] Press. 